\title{
MICROSATELLITE DNA VARIATION IN THE SIBERIAN STURGEON, ACIPENSER BAERI (ACTINOPTERYGII, ACIPENSERIFORMES, ACIPENSERIDAE), CULTURED IN A POLISH FISH FARM
}

\author{
Dorota FOPP-BAYAT ${ }^{*}$ \\ Division of Ichthyology, Faculty of Environmental Sciences and Fisheries, \\ University of Warmia and Mazury in Olsztyn, Poland
}

Fopp-Bayat D. 2010. Microsatellite DNA variation in the Siberian sturgeon, Acipenser baeri (Actinopterygii, Acipenseriformes, Acipenseridae), cultured in a Polish fish farm. Acta Ichthyol. Piscat. 40 (1): 21-25.

Background. The Siberian sturgeon, Acipenser baeri, is one of the most important sturgeon species cultured in Poland. The effective management of aquaculture production of this species requires contemporary knowledge of broodstock structure, mating patterns, and genetic diversity of broodstock. The aim of the present study was the application of microsatellite DNA analysis for estimation of gene diversity in the Siberian sturgeon farmed at a Polish fish farm.

Materials and Methods. Fin clips were randomly sampled from 94 specimens of Siberian sturgeon broodstock reared at the Wassosze Fish Farm near Konin, Poland. The analysed broodstock has been kept there since 1996, with new specimens being introduced annually. The fish were studied in 2007-2008. Genomic DNA for amplification of microsatellite loci was extracted using Chelex 100. Six microsatellite loci (Afu-19, Afu-39, Afu-68, $A f u B-68, S p l-163$, and Spl-168) were amplified for examination of the genetic variability of the studied fish.

Results. Within 94 individuals of the Siberian sturgeon, a total of 74 alleles were detected in six polymorphic microsatellite loci. The number of alleles per locus ranged from 8 to 18 , with an average allele number being 12 . The genetic diversity of six microsatellite loci varied from 0.686 to 0.811 .

Conclusion. This technology has great potential for use in aquaculture of sturgeon fish, especially when levels of genetic variation could be monitored and inbreeding controlled in commercial breeding programs.

Keywords: Siberian sturgeon, Acipenser baeri, aquaculture, microsatellite DNA, molecular markers

\section{INTRODUCTION}

Sturgeons (Acipenseridae) represent a very ancient group of fish called living fossil. Sturgeons are a source of two high-value products: boneless and very tasty meat and black caviar. Almost all sturgeon populations have been severely reduced to low levels, sometimes to extinction, due to overharvesting, pollution and damming of rivers (Birstein et al. 1997). Currently Acipenseriformes are ranked as one of the most threatened group of vertebrates with all of their species listed under the Convention on International Trade in Endangered Species of Wild Fauna and Flora (Anonymous 1994) Appendix I (2 species) and Appendix II (25 species).

The economic importance of sturgeons has prompted a growing aquaculture production of the Siberian sturgeon, Acipenser baeri Brandt, 1869, in Europe. The Siberian sturgeon has been domesticated in Europe and Asia (Chebanov and Billard 2001) and is now one of the most common and most important sturgeon species cul- tured in Poland. Currently this fish is the main source of sturgeon meat and black caviar produced by large international companies in Europe. A long period of sexual maturation of sturgeons (excluding the sterlet) is the most serious constraint in the aquaculture of acipenserid fishes. With relatively abundant broodstocks of $A$. baeri in Europe there is a good opportunity to increase production of valuable sturgeon products despite the decline in the natural populations of those fish.

The effective management of the aquaculture production of Siberian sturgeon requires contemporary knowledge of broodstock structure and mating patterns. The knowledge of the genetic structure of spawning populations is important for maintaining genetic diversity of a broodstock of the Siberian sturgeon while it is reared. The most reliable method for studying gene diversity in broodstock is application of microsatellite DNA analysis (May et al. 1997, McQuown et al. 2000, King et al. 2001, Pyatskowit et al. 2001, Fopp-Bayat et al. 2004, Fopp-Bayat 2007).

\footnotetext{
* Correspondence: Dr. Dorota Fopp-Bayat, Uniwersytet Warmińsko-Mazurski, Wydział Ochrony Środowiska i Rybactwa, Katedra Ichtiologii, ul. Oczapowskiego 5, 10-718 Olsztyn-Kortowo, Poland, phone: +48 89 5234772, fax: +48 89 5233754, e-mail: foppik@uwm.edu.pl.
} 
The use of microsatellite DNA as high polymorphic DNA markers has gained in importance for a number fish species over the past decade owing to the fact that it is an easy and powerful method (Norris et al. 1999, King et al. 2001, Fopp-Bayat 2004, Perales-Flores et al. 2007). The microsatellite, or short sequence repeat (SSR), is a powerful genetic marker, useful in many areas of fish genetics and breeding. Polymorphic microsatellite loci have been frequently applied to the analysis of genetic diversity, population genetic structure and genomic mapping (Clifford et al. 1998, Norris et al. 1999). These co-dominant markers have also been applied to the classification and taxonomy, parentage identification, germplasm conservation and breeding programme of food fish (Blouin et al. 1996, Chistiakov et al. 2005).

The major aim of the present study was the application of microsatellite DNA for estimation of gene diversity in Siberian sturgeon farmed at a Polish fish farm. The results will be applied to test the purity of hatchery broodstocks at Polish fish farms and to increase the efficiency of selective breeding and performance testing programs. The results of the research will provide baseline data for the development of scientifically sound management of the farmed Siberian sturgeon in Poland.

\section{MATERIAL AND METHODS}

Fin clips were sampled from 94 specimens of the Siberian sturgeon broodstock reared at the Wasosze Fish Farm near Konin, Poland. The analysed broodstock has been kept there since 1996, with new specimens being introduced annually. The fish were studied in 2007-2008. Genomic DNA for amplification of six microsatellite loci [Afu-19, Afu-39, Afu-68, AfuB-68, (May et al. 1997), Spl163, Spl-168 (McQuown et al. 2000)] was extracted using Chelex 100 (Walsh et al. 1991) (Table 1). All microsatellite loci were amplified using Polymerase Chain Reaction procedure (PCR). Reaction mixes for amplification microsatellites were prepared in a total volume of $25 \mu \mathrm{L}$ with $40 \mathrm{ng}$ DNA template, $1 \times \mathrm{PCR}$ reaction buffer (50 mM KCl, pH 8.5; Triton X-100), $0.4 \mathrm{mM}$ of each primer, $0.25 \mathrm{mM}$ ) of each deoxynucleotide triphosphate (dNTP), $3.3 \mathrm{mM} \mathrm{MgCl} 2$ and 0.6 unit Go Taq Flexi DNA Polymerase (Promega, Madison, WI, USA). Re-distilled water was used to bring the reaction mixture to the desired final volume. Amplification was conducted with a Mastercycler gradient thermocycler (Eppendorf, Germany), with initial denaturation at $94^{\circ} \mathrm{C}$ for $5 \mathrm{~min}$, followed by 35 amplification cycles $\left(94^{\circ} \mathrm{C}, 1 \mathrm{~min} ; 53-57^{\circ} \mathrm{C}\right.$, $30 \mathrm{~s} ; 72^{\circ} \mathrm{C}-30 \mathrm{~s}$; Table 1 ), and final elongation at $72^{\circ} \mathrm{C}$ for $5 \mathrm{~min}$. Aliquots containing PCR products and reaction buffer were electrophoresed using $6 \%$ polyacrylamide gel and DNA bands were visualized by the silver staining method (Tegelström 1986). Electrophoresis was conducted on a Bio-Rad SequiGen Sequencing Cell-system, and the gel size was $38 \times 30 \mathrm{~cm}$. Amplified fragments were sized by comparing migration with two DNA standards: фX 174 DNA/Hinf I DNA Step Ladder (Promega, Madison, WI, USA) and 25 bp DNA Step Ladder (Promega, Madison, WI, USA). The size and intensity of alleles in the studied microsatellite loci was estimated using Densitometer GS-800 with Quantity One software (Bio-Rad).

Allele frequencies, observed heterozygosity $\left(H_{o}\right)$, expected heterozygosity $\left(H_{e}\right)$ and information content (PIC) values for each locus were computed using the microsatellite toolkit for MICROSOFT EXCEL ${ }^{\mathrm{TM}}$ (Park 2001). The gene diversity was calculated based on heterozygosity value $(H)$.

$$
\bar{H}=\frac{2 n \times\left(1-\sum q_{i}{ }^{2}\right)}{2 n-1}
$$

$\bar{H}=$ heterozygosity value at locus,

$q_{i}=$ frequency of $i^{\text {th }}$ allele at locus,

$n=$ number of specimens.

For calculation of more loci the formula was:

Table 1

Primer sequences, annealing temperature and references of studied microsatellite loci in studied specimens of Siberian sturgeon, Acipenser baeri

\begin{tabular}{|c|c|c|c|}
\hline $\begin{array}{l}\text { Microsatellite } \\
\text { locus }\end{array}$ & Primer sequence & Temperature $\left[{ }^{\circ} \mathrm{C}\right]$ & Reference \\
\hline$A f u-19$ & $\begin{array}{l}\text { F..CATCTTAGCCGTCTGTGGTAC } \\
\text { R..CAGGTCCCTAATACAATGGC }\end{array}$ & 53 & May et al. 1997 \\
\hline Afu-39 & $\begin{array}{l}\text { F..TCCTGAAGTTCACACATTG } \\
\text { R..ATGGAGCATTATTGGAAGG }\end{array}$ & 57 & May et al. 1997 \\
\hline$A f u-68$ & $\begin{array}{l}\text { F..TTATTGCATGGTGTAGCTAAAC } \\
\text { R..AGCCCAACACAGACAATATC }\end{array}$ & 55 & May et al. 1997 \\
\hline$A f u B-68$ & $\begin{array}{l}\text { F..AACAATATGCAACTCAGCATAA } \\
\text { R..AGCCCAACACAGACAATATC }\end{array}$ & 55 & May et al. 1997 \\
\hline Spl-163 & $\begin{array}{l}\text { F..TGCTTGTAAACTGCCCCACT } \\
\text { R..CCACATGCAGTTTGAGCTGC }\end{array}$ & 57 & McQuown et al. 2000 \\
\hline Spl-168 & $\begin{array}{l}\text { F..CACTGATTCGCTACAACCGT } \\
\text { R..AGAAGGACTTGCAGTCCGAA }\end{array}$ & 57 & McQuown et al. 2000 \\
\hline
\end{tabular}




$$
\bar{H}=\frac{\sum_{r=1}^{r} \frac{2 n \times\left(1-\sum q_{i}^{2}\right)}{2 n-1}}{r}
$$

$\bar{H}=$ heterozygosity value at locus,

$q_{i}=$ frequency of $i^{\text {th }}$ allele at locus,

$n=$ number of specimens,

$r=$ number of studied loci.

The Polymorphism Information Content (PIC value) was calculated for each locus.

$$
P I C=1-\left(\sum_{i=1}^{n} p_{i}{ }^{2}\right)-\sum_{i=1}^{n} \sum_{j=i}^{n} 2 p_{i}{ }^{2} p_{j}{ }^{2}
$$

$p_{i}=$ frequency of $i^{\text {th }}$ allele in population,

$p_{j}=$ frequency of $j^{\text {th }}$ allele in population.

\section{RESULTS}

In this experiment, all six microsatellite loci were successfully amplified. The gels obtained with each of the six microsatellite loci were read taking into account the allele doses. Among the six studied microsatellite loci, three: $A f u-68, A f u B-68$, and Spl-168 were tetrasomic. Every tetrasomic locus was examined as two disomic loci and as a result the average frequency was considered for estimation of genetic variation. (Fig. 1 presents the example of microsatellite DNA variation at tetrasomic locus Spl-168 in Siberian sturgeon individuals). The size of the alleles at an individual locus varied between 100 base pairs (bp) and $252 \mathrm{bp}$. A total of 74 alleles were detected in the studied strain of Siberian sturgeon. The number of allele per locus ranged from 8 for locus $A f u$ - 39 to 18 for locus $A f u B-68$ with an average of 12 alleles per locus. Locus $A f u B-68$ occurred as the most variable locus among all the 18 alleles detected.

Table 2 presents expected heterozygosity, observed heterozygosity, number of alleles and PIC value at studied microsatellite loci in Siberian sturgeon. The studied groups of fish were characterized by various gene diversity in the analyzed microsatellite loci (Table 2). The most polymorphic loci are: Spl-163 and Spl-168 with the PIC-value 0.787 (Table 2).

\section{DISCUSSION}

The role of aquaculture in the production of the Siberian sturgeon has increased over the past 10 years in Poland. Aquaculture practices may decrease the genetic variability present in the farmed stock by breeding related individuals or by the use of small numbers of parents as the broodstock. Some selective breeding programs based on a small number of "superior" families may be related. Unless pedigree records are being maintained, there is a risk of selecting related individuals as parents and thereby increasing inbreeding (Norris et al. 1999). The effect of inbreeding is connected to high inbreeding depression of survival and growth trait (Su et al. 1996, Norris et al. 1999).

Breeding programs generally focusing on morphological data are insufficient for selection management. During several cycles of selection, it is difficult to know if the original genetic diversity present in the breeding pool has been maintained, increased through introduction or decreased through intense selection. The key point for solving such problems is the introduction of genetic surveys in broodstock. Genetic marker analyses have become an important tool for providing information regarding genetic variability, parentage relationships and the performances of lines in breeding programs.

Studies of genetic variation in farmed strains have usually utilised microsatellite DNA analysis. Application of genetic markers enable description of fish strain condition, including many parameters, for example gene diversity based on observed heterozygosity or Polymorphism Information Content (PIC). The PIC-value is an indicator of how many alleles a marker has, how evenly the frequencies of these alleles are distributed and if a marker has few alleles or many alleles but with only one being frequent, which is when the PIC-value will be low. The fact that all the loci in the present study had a PIC-value higher than 49\% (Table 2) could be considered as supporting selection of polymorphic markers for a study on parental relationship, paternity and genetic mapping (Blouin et al. 1996, Chistiakov et al. 2005). In recent years, genetic techniques have been found to be more powerful in analysing population structure in salmonid strains (Clifford et al. 1998) and acipenserid fishes (King et al. 2001, Fopp-Bayat 2004, 2007). There are numerous studies that clearly demonstrate loss of genetic diversity following hatchery culture in aquatic organisms, for example in Salmo salar (see Norris et al. 1999), Cyprinus carpio (see Desvignes et al. 2001, Bártfai et al. 2003), or Ictalurus punctatus (see Perales-Flores 2007).

Expected heterozygosity $\left(H_{\text {exp }}\right)$, observed heterozygosity $\left(H_{o b s}\right)$, numer of alleles $\left(\mathrm{N}_{\mathrm{a}}\right)$,

Table 2 and polymorphism information content (PIC) at studied microsatellite loci in Siberian sturgeon, Acipenser baeri

\begin{tabular}{llllcccrc}
\hline No. & Locus & $N_{o}$ & $H_{\text {exp }}$ & SD & $H_{\text {obs }}$ & SD & $N_{a}$ & $P I C$-value \\
\hline 1 & $A f u-19$ & 92 & 0.581 & 0.010 & 0.755 & 0.032 & 9 & 0.499 \\
2 & $A f u-39$ & 94 & 0.611 & 0.075 & 0.686 & 0.034 & 8 & 0.551 \\
3 & Afu-68 & 90 & 0.773 & 0.029 & 0.811 & 0.029 & 14 & 0.731 \\
4 & AfuB-68 & 95 & 0.781 & 0.033 & 0.718 & 0.023 & 18 & 0.749 \\
5 & Spl-163 & 94 & 0.809 & 0.016 & 0.771 & 0.031 & 13 & 0.787 \\
6 & Spl-168 & 94 & 0.814 & 0.012 & 0.611 & 0.035 & 12 & 0.787 \\
\hline
\end{tabular}




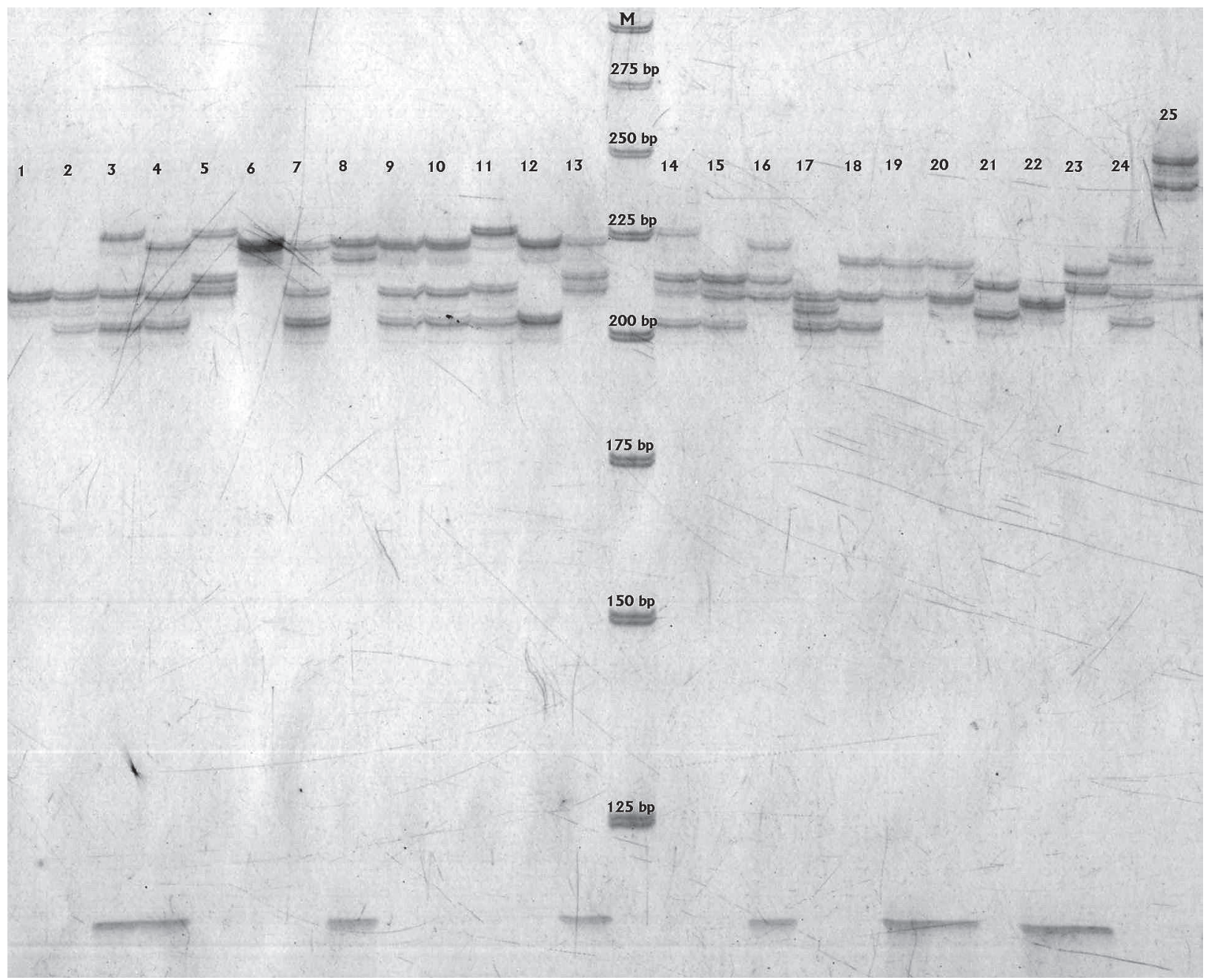

Fig. 1. Example of microsatellite DNA variation at locus Spl-168 in studied specimens of Siberian sturgeon, Acipenser baeri

In the presently reported study, most individuals exhibited banding patterns with more than two bands and asymmetry in band intensities for the three duplicated loci $(A f u-68$, $A f u B-68$, and Spl-168). The multiple banding patterns observed at locus are consistent with tetrasomy in the Siberian sturgeon and have also been shown in A. sinensis (see Zhu et al. 2002), and A. fulvescens (see Pyatskowit et al. 2001, McQuown et al. 2002). Polyploidization may also play a role in failed amplification, as competitive hybridization with the non-homologous (homeologous) sets of chromosomes may lead to variable amplification and hence problems in replication within individuals or from parents to offspring (Zhu et al. 2002).

Similar studies have been conducted on a population of A. sinensis in the Yangtze River and a low heterozygosity and a low percentage of PIC value have been reported based on allozymes and RAPDs analyses (Zhu et al. 2002). It has been suggested that the microsatellite DNA analysis is more suitable for studying genetic diversity in sturgeons. Zhu et al. (2002) show that mature individuals and juveniles (primarily produced naturally) have the same number of alleles, suggesting the population has not lost very much genetic variation to date. This can be contrasted with the results reported by Norris et al. (1999), who demonstrated a considerable loss of rare alleles in a farmed Atlantic salmon, Salmo salar, population was demonstrated, which did not coincide with a significant difference in overall heterozygosity between the farmed and wild strains.

The present study has clearly demonstrated the potential of genetic assignment of the Siberian sturgeon in aquaculture, providing farmers with a tool to monitor various aspects of production and management. However, Siberian sturgeon producers are now very interested in designing genetic improvement regimes and the present study is a valuable step in defining the genetic variation in the actual commercial strain of the Siberian sturgeon in Poland. The next stage should involve studying genetic diversity in other strains of the Siberian sturgeon cultured in Poland.

\section{ACKNOWLEDGEMENTS}

The study was supported by the research project funded by the Ministry of Science and Higher Education, Poland (MNiSW) No. N311 010 32/0654. I would like to thank Ms. Elżbieta Fopp and Mr. Andrzej Fopp from the Wąsosze Fish Farm for kindly providing fish for the study. I also thank Mr. Paweł Woźnicki for laboratory assistance. 


\section{REFERENCES}

Anonymous 1994. Red list of threatened animals. Prepared by the IUCN Species Survival Commission. IUCN, Gland, Switzerland.

Bártfai R., Egedi S., Yue G.H., Kovács B., Urbányi B., Tamás G., Horváth L., Orbán L. 2003. Genetic analysis of two common carp broodstocks by RAPD and microsatellite markers. Aquaculture 219 (1-4): 157-167.

DOI: 10.1016/S0044-8486(02)00571-9.

Birstein V.J., Waldman J.R., Bemis W.E. (eds.) 1997. Sturgeon biodiversity and conservation. Kluwer Academic \& Plenum Publishers, New York.

Blouin M.S., Parsons M., Lacaille V., Lotz S. 1996. Use of microsatellite loci to classify individuals by relatedness. Molecular Ecology 5 (3): 393-401. DOI: 10.1046/j.1365-294X.1996.00094.x.

Chebanov M., Billard R. 2001. The culture of sturgeons in Russia: production of juveniles for stocking and meat for human consumption. Aquatic Living Resources 14 (6): 375-381. DOI: 10.1016/S0990-7440(01)01122-6.

Chistiakov D.A., Hellemans B., Haley C.S., Law A.S., Tsigenopoulos C.S., Kotulas G., Bertotto D., Libertini A., Volckaert F.A.M. 2005. A microsatellite linkage map of the European sea bass Dicentrarchus labrax L. Genetics 170: 1821-1826. DOI: 10.1534/genetics.104.039719.

Clifford S.L., McGinnity P., Ferguson A. 1998. Genetic changes in an Atlantic salmon population resulting from escaped juvenile farm salmon. Journal of Fish Biology 52 (1): 118-127. DOI: 10.1111/j.1095-8649.1998.tb01557.x.

Desvignes J.F., Laroche J., Durand J.D., Bouvet Y. 2001. Genetic variability in reared stocks of common carp (Cyprinus carpio L.) based on allozymes and microsatellites. Aquaculture 194 (3-4): 291-301. DOI: $10.1016 / \mathrm{S} 0044-8486(00) 00534-2$.

Fopp-Bayat D. 2004. Genetic identification of sturgeons, and sturgeon-derived food products: meat and caviar. Archives of Polish Fisheries 12 (Suppl. 2): 231-241.

Fopp-Bayat D. 2007. Verification of meiotic gynogenesis in Siberian sturgeon (Acipenser baeri Brandt) using microsatellite DNA and cytogenetical markers. Journal of Fish Biology 77 (Supplement C): 478-485. DOI: 10.1111/j.1095-8649.2007.01704.x.

King T.L., Lubinski B.A., Spidle A.P. 2001. Microsatellite DNA variation in Atlantic sturgeon (Acipenser oxyrinchus oxyrinchus) and cross-species amplification in the Acipenseridae. Conservation Genetics 2 (2): 103-119. DOI: 10.1023/A:1011895429669.

May B., Krueger C.C., Kincaid H.L. 1997. Genetic variation at microsatellite loci in sturgeon: primer sequence homolo- gy in Acipenser and Scaphirhynchus. Canadian Journal of Fisheries and Aquatic Sciences 54 (7): 1542-1547. DOI: 10.1139/cjfas-54-7-1542.

McQuown E.C., Sloss B.L., Sheehan R.J., Rodzen J., Tranah G.J., May B. 2000. Microsatellite analysis of genetic variation in sturgeon: New primer sequences for Scaphirhynchus and Acipenser. Transactions of the American Fisheries Society 129:1380-1388.

DOI: 10.1577/1548-8659(2000)129<1380:MAOGVI >2.0.CO;2.

Norris A.T. Bradley D.G. Cunningham E.P. 1999. Microsatellite genetic variation between and within farmed and wild Atlantic salmon (Salmo salar) populations. Aquaculture 180 (3-4): 247-264.

DOI: $10.1016 / \mathrm{S} 0044-8486(99) 00212-4$.

Park S.D.E. 2001. Trypanotolerance in West African cattle and the population genetic effects of selection. PhD Thesis, University of Dublin.

Perales-Flores L.E., Sifuentes-Rincón A.M., de León F.J.G. 2007. Microsatellite variability analysis in farmed catfish (Ictalurus punctatus) from Tamaulipas, Mexico. Genetics and Molecular Biology 30 (3): 570-574. DOI: 10.1590/S1415-47572007000400011.

Pyatskowit J.D., Krueger C.C., Kincaid H.L., May B. 2001. Inheritance of microsatellite loci in the polyploid lake sturgeon (Acipenser fulvescens). Genome 44 (2): 185-191. DOI: 10.1139/gen-44-2-185.

Su G.-S., Liljedahl L.-E., Gall G.A.E. 1996. Effects of inbreeding on growth and reproductive traits in rainbow trout (Oncorhynchus mykiss). Aquaculture 142 (3-4): 139-148. DOI: 10.1016/0044-8486(96)01255-0.

Tegelström H. 1986. Mitochondrial DNA in natural populations: an improved routine for the screening of genetic variation based on sensitive silver staining. Electrophoresis 7 (5): 226229. DOI: 10.1002/elps.1150070508.

Walsh P.S., Metzger D.A., Higuchi R. 1991. Chelex 100 as a medium for simple extraction of DNA for PCR-based typing from forensic material. Biotechniques 10: 506-513.

Zhu B., Zhou F., Cao H., Shao Z, Zhao N., May B., Chang J. 2002. Analysis of genetic variation in the Chinese sturgeon, Acipenser sinensis: estimating the contribution of artificially produced larvae in a wild population. Journal of Applied Ichthyology 18 (4-6): 301-306. DOI: 10.1046/j.1439-0426.2002.00379.x.

Received: 17 July 2009

Accepted: 1 December 2009

Published electronically: 25 June 2010 